9. Про Загальнодержавну програму адаптації законодавства України до законодавства Європейського Союзу: Закон України від 18 березня 2004 р. // Відомості Верховної Ради України, 2004. № 29. Ст. 367.

10. Вишняков О. К. Апроксимація правового забезпечення цивільних майнових відносин в Україні до умов внутрішнього ринку Свропейського Союзу: дис. ... док. юрид. наук: 12.00.03. Одеса, 2008. С. 5.

\title{
Luts V. System-forming role of the category «contract» in the private law of Ukraine
}

The article clarified the concept and essence of a civil contract, its place in the mechanism of legal regulation of civil relationships, system-forming role of the category "contract» for industries and institutions of civil rights, but also to clarify the relevant concepts in other areas of law (such as private, and public).

Keywords: contract, civil contract, the construction contract, obligations, legal agreements, mechanisms of legal regulation.

\section{МЕТОДОЛОГІЧНІ ПІДХОДИ ДО ПОНЯТТЯ «ДИФЕРЕНЦАЦІЯ» В ЮРИДИЧНІЙ НАУЦІ}

\section{Бобрик B. I.,}

кандидат юридичних наук, старший науковий співробітник НДІ приватного права і підприємництва імені академіка Ф. Г. Бурчака НАПрН Украӥни

В статті висвітлюються методологічні філософські та загальнонаукові підходи до поняття «диференціація» в праві та правовій науці. Розкривається походження иього терміна та його загальнотеоретичне значення. Особлива увага приділяється діалектичній єдності диференціації та інтеграції права, які є парними категоріями (діалектичними протилежностями), а також диференційноінтегращійним прочесам, наслідком яких є формування системи права та окремих системних правових явищ.

Ключові слова: диференціація, диференціація права, інтеграція, система права, норма права.

Постановка проблеми. Термін «диференціація» не є правовим [13, С. 72] і нечасто застосовується в актах законодавства України. Проте вже тривалий час це поняття використовується у філософії, загальній науці (метанауці) та в різних природничих і суспільних науках (біології, хімії, математиці, етнографії, соціології, лінгвістиці тощо). Останнім часом це поняття дедалі частіше застосовується й правознавцями, і не лише при дослідженні проблем теорії права (системи права, спеціалізації права тощо), а й у галузево-правових науках (кримінальному праві, трудовому праві, процесуалістиці тощо). Проте застосування цього терміна в юридичній літературі не завжди є методологічно вірним, 3 огляду на що виникає потреба з'ясувати методологічні підходи до його розуміння та загальну сутність.

Аналіз останніх досліджень і публікацій. Диференціацію в загальній теорії права в контексті системи права та спеціалізації права досліджували такі науковці, як: С. С. Алексєєв, А. М. Асадов, К. А. Бєліков, Т. В. Драхенберг, О. В. Мартишин, А. І. Граціанов, С. А. Громов, Р. М. Дудник, В. Л. Кулапов, Є. Г. Потапенко, Н. М. Оніщенко, Д. Є. Петров, В. Ф. Попондопуло, А. М. Рабец, Н. В. Разуваєв, В. П. Реутов, І. Н. Сенякін, А. Ф. Черданцев, Г. Ф. Шершеневич, В. Ф. Яковлєв та інші. В рамках науки цивільного процесуального права проблемам диференціації судочинства та процесуального права приділяли увагу Н. А. Громошина, О. В. Слєпченко, Д. В. Слинько, О. С. Ткачук та інші. Проте в такому аспекті, як в цій статті, науковий аналіз диференціації в праві не проводився та в літературі не висвітлювався.

Метою дослідження є з'ясування загальних методологічних підходів до поняття «диференціація» в праві.

Виклад основного матеріалу. При визначенні поняття диференціації в праві потрібно насамперед звернутись до етимології та означення слова «диференціація», а також його філософського значення. Це слово походить від лат. «differentia», що українською мовою перекладається як «різниця», «відмінність», «багатоваріантність» тощо [1]. В Словнику української мови (СУМ-11) вказується таке означення слова «диференціація» - «поділ, розчленування чого-небудь на окремі різнорідні елементи» $[28$, c. 289].

У філософії поняття «диференціація» є поліаспектним, адже йому надається кілька значень: 1) поділ, розчленування, розшарування цілого на частини, різноманітні та різні форми і ступені; 2) виникнення нових органів, частин, наділених спеціалізованими функціями, наслідком чого $\epsilon$ поступове ускладнення системи (зокрема організму) при розвитку; 3) послідовне визрівання якісних відмінностей, визначень [32, с. 58]. Філософи розрізняють функціональну диференціацію, в ході якої розширюється коло функцій, які виконуються елементами системи, що розвивається, і структурну, в ході якої в системі виділяються підсистеми, що реалізують ті чи інші функції. Іноді під диференціацією 
розуміється диференційованість, тобто наявність в цілому сукупності спеціалізованих частин, рівнів, підсистем [33, с. 170].

Загальновизнано те, що поняття «диференціація» було введено у філософію та соціальні науки наприкінці XIX ст. англійським філософом і одним із основоположників соціології Г. Спенсером (Herbert Spencer), який запозичив його з природничих наук. Термін «диференціація» використовувався Г. Спенсером для обгрунтування його вчення про еволюцію та соціологічні теорії, в тому числі органічного походження держави. В широкому розумінні Г. Спенсер вважав, що диференціація - це поява 3 якоїсь однорідності різноманіття; розчленовування на форми і ступені; виникнення в організмі в процесі розвитку морфологічних і функціональних відмінностей. Вказане поняття він вживав для позначення антиподу інтеграції - виникнення цілісності, єдності в системі, заснованих на взаємодоповнюваності та взаємозалежності окремих елементів. Г. Спенсер розглядав диференціацію та інтеграцію як основні елементи всезагальної еволюції матерії від простого до складного, в тому числі на соціальному рівні. У праці «Основи соціології» Г. Спенсер розвинув положення про те, що первинні органічні диференціації відповідають первинним відмінностям у відносному стані частин організму, а саме, «знаходженню всередині». Описавши первинну диференціацію, Г. Спенсер сформулював дві закономірності цього процесу. Перша - залежність взаємодії соціальних інституцій від рівня організації суспільства: низький рівень організації характеризується слабкою інтеграцією частин, високий - сильнішою залежністю кожної частини від усіх інших. Друга - пояснення механізму соціальної диференціації та походження соціальних інституцій як наслідок того, що в індивідуальному, як і в соціальному, процес агрегації постійно супроводжується процесом організації, причому останній підпорядкований в обох випадках одному загальному закону, який полягає в тому, що послідовна диференціація відбувається завжди від більш загального до більш спеціального [9].

Ідеї Г. Спенсера про соціальну диференціацію розвивали в своїх дослідженнях багато інших соціологів, зокрема, Е. Дюркгейм, М. Вебер, С. Норт, Т. Парсонс, Н. Луман, А. Етціоні, С. Ейзенштадт, Ф. Ріггс та інші. В узагальненому вигляді їх погляди на соціальну диференціацію полягають в тому, що диференціацією $є$ як наявний стан соціальної структури, так і процес, який веде до виникнення різних видів діяльності, ролей, груп, які спеціалізуються на виконанні окремих функцій, необхідних для самозбереження соціальної системи. Також в соціологічних джерелах $\epsilon$ так звані таксономічні визначення диференціації, за яких цей термін позначає просто відмінності соціальних ролей, статусів, груп, організацій тощо [25, с. 142].

Внаслідок розвитку поглядів Г. Спенсера та інших філософів і соціологів термін «диференціація» набув значного поширення в метанауці, в якій він використовується спільно 3 «інтеграцією» як парні категорії. Так, В.К. Сидоренко та П. В. Дмитренко зазначають, що для багатьох наук нині $\epsilon$ характерним діалектичне поєднання процесів диференціації та інтеграції наукових знань. Таке поєднання $\epsilon$ проявом двох закономірностей людського пізнання: відобразити єдність і цілісність світу, з одного боку, виявити закономірності специфічних часткових структур матерії в ії багатстві та різноманітності - з іншого. Перша тенденція характеризує процеси синтезу, інтеграції знань, друга відображає процеси спеціалізації та диференціації. Диференціація та інтеграція, як дві взаємно протилежні тенденції в розвитку науки, своєрідно проявляють дію закону єдності та боротьби двох протилежностей у пізнанні. Ці дві тенденції не тільки взаємно виключають, а й передбачають, обумовлюють і збагачують одна одну, становлячи діалектичну єдність [26, с. 58-59].

Із загальнонаукової та методологічної точки зору будь-яка складна система постійно зазнає дії двох зустрічно-спрямованих сил - відштовхування та притягання. У філософському розумінні сила відштовхування пов'язана 3 дробленням елементів структури і ослабленням іiі цілісності, сила притягання спрямована на укрупнення компонентів системи, посилення іiі узгодженості і єдності. Діалектичне співвідношення тенденцій відштовхування та притягання у вигляді їх єдності, відмінностей, суперечностей і взаємодії в рамках одного цілого системного утворення виступає основою його прогресу $[21$, с. 98]. В цьому проявляється така закономірність діалектичного розвитку, як закон єдності та боротьби протилежностей.

Як зазначає А. М. Авер'янов, в діалектичній взаємодії процесів ділення та поєднання закладені передумови не тільки розвитку і вдосконалення, а й самого виникнення системи [3, с. 173]. Для появи системи необхідне існування певної сукупності елементів, які, з одного боку, утворені в результаті поділу якоїсь єдності, а з іншого - володіють тотожними властивостями, що дають можливість їх подальшого об'єднання в ціле. I в цьому плані видається правильною в методологічному відношенні висловлена А. М. Авер'яновим думка про те, що диференціація тотожності є необхідною умовою розвитку. Разом з тим, зазначає автор, відбувається процес ускладнення зв'язків між елементами, що диференціюються, їх субпідрядність, що і веде до становлення системи як цілого. Іншими словами, одночасно відбувається інтеграція диференційованих елементів [2, с. 46].

Поділяючи таке розуміння, російський дослідник диференціації та інтеграції структурних утворень системи права Д. Є. Петров зазначає, що за своєю суттю диференційно-інтеграційні 
процеси, які протікають в системних явищах, є організаційними процесами. Їх завдання - організувати систему таким чином, щоб зробити генетичні, структурні, функціональні зв'язки між елементами (частинами) максимально повними, тобто ускладнити взаємозалежність між ними. Тим самим система стає організованим єдиним цілим [21, с. 98].

Особливу увагу процесам диференціації та інтеграції в складних системах приділяв один із основоположників системного підходу і науки тектології О. О. Богданов. Він вибудував загальну концепцію системи за допомогою виокремлення та аналізу двох найбільш істотних і універсальних системно-організаційних механізмів: формуючого та регулюючого. О. О. Богданов розглядав розходження та сходження форм, які стосуються вже не окремого комплексу і пов'язаних 3 ним організаційних процесів, а організаційних закономірностей, що враховують існування двох і більше комплексів. Його закон розходження (під назвою «системна диференціація» або «системне розходження») описує зміну системи, що складається 3 окремих частин і означає організаційний процес, пов'язаний зі зростанням відмінностей між елементами комплексу і появою дезінгресій - розривів внутрішніх зв’язків, що в результаті призводить або до дезорганізації всього комплексу, або до кардинальної його зміни [8].

Таким чином, категорія «диференціації» («розходження», «ділення») в загальній науковій методології розглядається в єдності з його парною категорією - «інтеграцією» («сходженням», «поєднанням»), яким відводиться особливе місце в загальнотеоретичному обгрунтуванні складних систем, в тому числі соціальних. До таких систем, безумовно, належать і право, і пов'язана з ним діяльність - юридична. Відтак загальнонаукові знання щодо «диференціації», з урахуванням їі зв’язку з інтеграцією, і досвід їх застосування цілком придатні для використання в юридичній науці. Однак юридична наука не повинна дублювати чи некритично запозичувати відповідні загальнонаукові чи філософські знання, так само як і за допомогою софістичних прийомів намагатися через призму загальнонаукових категорій надати традиційним уявленням про правове буття нового розуміння чи форми. Саме тому категорія «диференціації» в загальноправовій і галузевих правових науках набуває свого особливого значення, що враховує специфіку відповідної сфери знань.

В теорії права доволі поширеними є погляди на диференціацію (чи спеціалізацію) права як категорію, що разом з інтеграцією обумовлює таку властивість права як системність, ділення права на галузі, а також визначає спеціалізацію права, законодавства та правового регулювання [5-7; 10-12; $15 ; 18 ; 20 ; 22-24 ; 27 ; 29 ; 35]$. Так, С. С. Алексєєв спеціалізацію права вважає однією 3 його властивостей, одним із проявів власне правового розвитку, який втілює i зовнішні чинники, що впливають на право, і внутрішні потреби правової системи. Суть спеціалізації права вчений розкриває через «поділ праці між нормами», в результаті якого ті чи інші норми й їх комплекси дедалі більше зосереджуються на виконанні певних операцій, конкретизується зміст норм і одночасно відбувається інтеграція в регулюванні суспільних відносин. Основними, частково перехресними різновидами спеціалізації права С. С. Алексєєв називає:

- диференціацію (предметну та функціональну), тобто розгалуження нормативного змісту правового регулювання, набуття тією чи іншою його галуззю дедалі більш специфічних рис;

- конкретизацію, тобто деталізацію змісту нормативного регулювання, дедалі докладніше регулювання окремих сторін і елементів даних суспільних відносин;

- інтеграцію, тобто узагальнену регламентацію того єдиного, що збігається, що властиво групам суспільним відносин, їх принципам, засадам тощо.

У процесі спеціалізації відокремлюються групи норм, що виконують ті або інші функції при здійсненні правового регулювання. Процес спеціалізації обумовлює перетворення нормативної системи в кінці кінців на комплекс головним чином спеціалізованих нормативних положень; звідси - необхідність при аналізі окремої юридичної норми розуміти їі спеціалізований характер і враховувати іiі зв'язки 3 багатьма іншими нормами-приписами [4, с. 37-38].

В. Л. Кулапов і С. Г. Потапенко, досліджуючи теоретичні основи правової інтеграції, на основі положень розробленої С. С. Алексєєвим конструкції спеціалізації виключають інтеграцію як ії форму [17, с. 12-13]. Такий підхід в цілому був підданий критиці Д. С. Петровим, який наголошує на тому, що в такому разі ототожнюється змістовна та формальна сторони права. На його переконання, категорія «спеціалізація» має відображати процес ділення елементів системи законодавства, а поняття «диференціація» має слугувати з'ясуванню процесів поділу в системі права. 3 огляду на це зазначений автор вважає, що спеціалізація законодавства є однією з форм диференціації в праві, а не навпаки [21, с. 110-111].

Зважаючи на такі міркування, Д. Є. Петров дещо ширше розглядає диференціацію та інтеграцію в системі права, адже вважає їх одночасно тенденціями, процесами і закономірностями їі розвитку. Як тенденції вони виражають можливість, свого роду «схильність» структурних утворень системи права розвиватися у відповідних напрямах. Як процеси вони представляють дану можливість, що стала реальним фактом. Диференціація та інтеграція є процесами, що проходили раніше і проходять в 


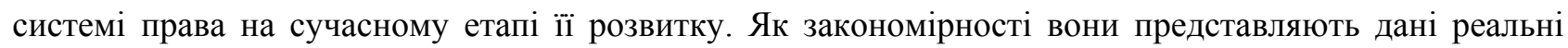
факти, набувають статусу необхідності. Вказаний автор зазначає, що стосовно системи права процеси диференціації та інтеграції ведуть до ускладнення структури права, утворення нових структурних елементів: норм, інститутів, галузей, появи нових внутрішніх зв'язків. Найпростіший приклад диференціації - це поява нового різновиду норм права, а інтеграції - це об'єднання низки норм в єдиний комплекс, в інститут права [21, с. 105, 107-108].

Г. Ф. Шершеневич вважав диференційно-інтеграційний процес основним механізмом правотворення. Він зазначав, що процес правотворення полягає саме в поступовій дедалі більшій диференціації права в сфері правил співжиття, в диференціації, що відбувається всередині права, і в інтеграції норм права, яка виражається в тому, що, незважаючи на постійне зростання числа норм права, відбувається поєднання і координування їх в інститути [34, с. 508].

Усвідомлюючи єдність процесів диференціації та інтеграції в праві та їх взаємозв'язок відповідно до діалектичного закону єдності та боротьби протилежностей, варто зосередитись й на їх відмінностях. Як зазначає Д. Є. Петров, основні відмінності процесів диференціації та інтеграції пов’язані з їх метою і спрямуванням обробки правового матеріалу. Правова інтеграція виражається в зближенні та об’єднанні правових приписів, іiі мета - створення загального уніфікованого в певній сфері суспільних відносин правового режиму. Процес диференціації, навпаки (інакше ці категорії не розглядалися б як діалектичні протилежності), полягає в дробленні та виділенні правових приписів. Мета диференціації в праві - всебічне врегулювання суспільних відносин з урахуванням їх соціально-економічної, політичної, регіональної та іншої специфіки [21, с. 106].

Висновки. Наведені вище підходи щодо диференціації в праві не можуть претендувати на роль універсального науково-правового підходу до даного поняття, адже не враховують те, що поділяються (розходяться) не лише елементи системи права, а й ті явища, які породжуються правом, зокрема правова діяльність. Тому загальне науково-правове поняття диференціації має відображати відповідну властивість будь-яких системних правових явищ, а також враховувати те, що диференціація права обумовлює диференціацію відповідних правових явищ (ї проявів). У такому контексті в юридичній науці диференціація має вживатися завжди для позначення закономірного та системного поділу права та інших правових явищ (кожного окремо) задля ефективного вирішення завдань, які стоять перед ними.

\section{СПИСОК ВИКОРИСТАНОЇ ЛІТЕРАТУРИ:}

1. Differentia. Переклад та визначення в онлайн-словнику. Електронний ресурс. URL: https://uk.glosbe.com/ la/uk/differentia (дата звернення: 15.10.2017).

2. Аверьянов А. Н. Категория «система» в диалектическом материализме. М., 1974. 70 с.

3. Аверьянов А. Н. Системное познание мира: методологические проблемы. М., 1985. 263 с.

4. Алексеев С. С. Общая теория права: в 2-х т. Т. 2. М.: «Юридическая литература», 1982. 360 с.

5. Алексеев С. С. Структура советского права. М., 1975. 264 с.

6. Асадов А. М., Драхенберг Т. В. К вопросу о телеологическом критерии дифференциации системы российского права // Проблемы права. 2012. № 2. С. 176-181

7. Беликов К. А. Дифференциация системы права: критика традиционных критериев, выдвижение новых подходов (с позиций субъекта права) // Юридическая мысль. Научно-практический журнал, 2007. № 3 (41). C. $5-16$.

8. Богданов А. А. Тектология: (Всеобщая организационная наука). В 2-х кн. М.: Экономика, 1989. Кн. 1.304 c.

9. Галушко К. Ю. Спенсер Герберт // Енциклопедія історії України: у 10-и т. / Редкол.: В. А. Смолій (голова) та ін.; Інститут історії України НАН України. К.: Наук. думка, 2012. Т. 9. С. 742.

10. Граціанов А. І. Процес систематизації та уніфікації законодавства і розвиток правової системи України: автореф. дис. ... канд. юрид. наук: 12.00.01. Національна академія внутрішніх справ України. K., 2004. 185 c.

11. Громов И. А., Мацкевич А. Ю., Семенов В. А. Западная теоретическая социология. СПб.: Ольга, 1996. 286 с.

12. Громов С. А. Соотношение частного и публичного права в российской системе права: тенденции дифференциации и интеграции: дис. ... канд. юрид. наук. СПб., 2004. 226 с.

13. Громошина Н. А. Дифференциация, унификация и упрощение в гражданском судопроизводстве. М.: Проспект, 2010.264 с.

14. Давыдов Ю. Н. История теоретической социологии. Социология второй половины XX начала XXI века. Учебное пособие для вузов. М.: Академический проект, 2010. 526 с.

15. Дудник Р. М. Галузева диференціація українського права: поняття, рівні і тенденції розвитку: дис.. ... канд.. юрид. наук : 12.00.01. Одеса, 2016. 209 с. 
16. Дюркгейм Э. Социология. Ее предмет, метод, предназначение / Пер. с франц., составление, послесловие и примечания А. Б. Гофмана. М.: Канон, 1995. 352 с.

17. Кулапов В. Л., Потапенко Е. Г. Теоретические основы правовой интеграции: монографія. М.: Юрлитинформ, 2011. 184 с.

18. Мартышин О. В. О дифференциации отраслей права // Труды Московской государственной юридической академии: сб. ст. М., 2002. № 9. С. 32-34.

19. Мірошниченко М. І. Історія вчень про державу і право: навч. посіб. / М. I. Мірошниченко, В. І. Мірошниченко; Нац. акад. внутр. справ України. К.: Атіка, 2001. 224 с.

20. Оніщенко Н. М. Правова система: проблеми теорії. К.: Інститут держави і права ім. В. М. Корецького, 2002. $352 \mathrm{c}$.

21. Петров Д. Е. Дифференциация и интеграция структурных образований системы российского права: дис. ... док. юрид. наук: 12.00.01. Саратов, 2015. 505 с.

22. Попондопуло В. Ф. Проблемы единства и дифференциации российского права и законодательства // Российский юридический журнал, 2011. № 1 (76). С. 26-37.

23. Рабец А. М. Интеграция и дифференциация в праве // Труды Московской государственной юридической академии: сб. ст. М., 2002. № 9. С. 54-57.

24. Разуваев Н. В. Правовая система и критерии отраслевой дифференциации права // Правоведение, 2002. № 3. C. 31-55.

25. Российская социологическая энциклопедия / Под общ. ред. Г. В. Осипова. М.: НОРМАИНФРА-М, 1999. $672 \mathrm{c.}$

26. Сидоренко В. К., Дмитренко П. В. Основи наукових досліджень: навчальний посібник для вищих педагогічних закладів освіти. К.: ДІНІТ, 2000. 259 с.

27. Слинько Д. В. Загальнотеоретичні чинники диференціації системи процесуального права // Вісник Харківського національного університету ім. Каразіна. 2015. № 1151. Серія «Право». Вип. № 19. C. 21-25.

28. Словник української мови: в 11-ти томах. Київ: Наукова думка, 1970-1980. Том 2, 1971. 452 с.

29. Специализация и унификация Российского законодательства. Проблемы теории и практики / Сенякин И. Н. Под ред. Байтин М. И. Саратов: Изд-во Сарат. ун-та, 1993. 194 с.

30. Тарент И. Г. Историко-философский анализ тектологии А. А. Богданова: дис. ... канд. филос. наук по специальности 09.00.03. Москва, 2003. 190 с.

31. Ткачук О. С. Реалізація судової влади у цивільному судочинстві України: структурнофункціональний аспект: дис.. ... док. юрид. наук: 12.00.03. Харків, 2016. 547 с.

32. Философская энциклопедия: в 5-и т. / глав. ред. Ф. В. Константинов. М.: Советская энциклопедия, 1962. Т. 2: Дизъюкция - комическое. 575 с.

33. Философский энциклопедический словарь / Гл. редакция: Л. Ф. Ильичёв, П. Н. Федосеев, С. М. Ковалёв, В. Г. Панов. М.: Советская энциклопедия, 1983. 840 с.

34. Шершеневич Г. Ф. Общая теория права. М.: Изд. Бр. Башмаковых, 1911. 698 с.

35. Яковлев В. Ф. Отраслевая дифференциация и межотраслевая интеграция как основы системы законодательства // Правоведение, 1975. № 1. С. 16-23.

Bobryk V. Methodological approaches to the concept of «Differentiation» in legal science

The article highlights methodological philosophical and general scientific approaches to the notion of «differentiation of law». The origin of this term and its general theoretical significance are revealed. Particular attention is paid to the dialectical unity of differentiation with the integration of law, which are paired categories (dialectical opposites), and also to differential-integration processes, the consequence of which is the formation of a system of law and individual legal phenomena.

Keywords: differentiation, differentiation of law, integration, system of law, rule of law.

\section{ЦИВІЛЬНО-ПРАВОВА ТАКСОНОМІЯ ЮРИДИЧНИХ ОСІБ ПРИВАТНОГО ПРАВА}

Кочин В. В.,

https://doi.org/10.32849/2409-9201.2018.18.4

кандидат юридичних наук, завідувач відділу методологї приватноправових досліджень НДІ приватного права і підприємниитва імені академіка Ф. Г. Бурчака НАПрН Украӥни

Статтю присвячено систематизаиії юридичних осіб приватного права та виділенню таких таксонів відповідно до класифікаційних критеріїв: підтип, рід, група, підгрупа, форма, допоміжна форма. Встановлено, що природні таксони надають можливість розмежувати цивільно-правові відносини щэодо формування юридичної особи як організації (niдтип), участі у підприємницьких та 